\title{
Partial purification and characterization of glutathione S-transferase from the somatic tissue of Gastrothylax crumenifer (Trematoda: Digenea)
}

\author{
Sakil Ahmed ${ }^{1}$, Aamir Sohail ${ }^{2}$, Sabiha Khatoon ${ }^{1}$, Shabnam Khan ${ }^{1}$ and Mohammad Khalid Saifullah ${ }^{1}$
}

\begin{abstract}
1. Section of Parasitology, Department of Zoology, Aligarh Muslim University, Aligarh, Uttar Pradesh, India;
2. Department of Biochemistry, Aligarh Muslim University, Aligarh, Uttar Pradesh, India.

Corresponding author: Mohammad Khalid Saifullah, e-mail: mkhalidsaif@yahoo.com

Co-authors: SA: sakil007@gmail.com, AS: aamirsohail4@gmail.com, SK: sabiha.khan9876@gmail.com, SHK: kshabnam746@gmail.com
\end{abstract}

Received: 19-08-2017, Accepted: 15-11-2017, Published online: 21-12-2017

doi: 10.14202/vetworld.2017.1493-1500 How to cite this article: Ahmed S, Sohail A, Khatoon S, Khan S, Saifullah MK (2017) Partial purification and characterization of glutathione S-transferase from the somatic tissue of Gastrothylax crumenifer (Trematoda: Digenea), Veterinary World, 10(12): 1493-1500.

\begin{abstract}
Aim: Aim of the present study was to carry out the partial purification and biochemical characterization of glutathione S-transferase (GST) from the somatic tissue of ruminal amphistome parasite, Gastrothylax crumenifer (Gc) infecting Indian water buffalo (Bubalus bubalis).

Materials and Methods: The crude somatic homogenate of Gc was subjected to progressive ammonium sulfate precipitation followed by size exclusion chromatography in a Sephacryl S 100-HR column. The partially purified GST was assayed spectrophotometrically, and the corresponding enzyme activity was also recorded in polyacrylamide gel. GST isolated from the amphistome parasite was also exposed to variable changes in temperature and the $\mathrm{pH}$ gradient of the assay mixture.

Results: The precipitated amphistome GST molecules showed maximum activity in the sixth elution fraction. The GST subunit appeared as a single band in the reducing polyacrylamide gel electrophoresis with an apparent molecular weight of $26 \mathrm{kDa}$. The GST proteins were found to be fairly stable up to $37^{\circ} \mathrm{C}$, beyond this the activity got heavily impaired. Further, the GST obtained showed a $\mathrm{pH}$ optima of 7.5.
\end{abstract}

Conclusion: Present findings showed that GST from Gc could be conveniently purified using gel filtration chromatography. The purified enzyme showed maximum stability and activity at $4^{\circ} \mathrm{C}$.

Keywords: Bubalus bubalis, Gastrothylax crumenifer, glutathione S-transferase, purification, somatic tissue.

\section{Introduction}

Amphistomes are digenetic trematodes comprising a characteristic posteriorly located muscular acetabulum. There are more than 70 species of amphistome parasites all over the world [1], particularly in the hot and humid land stretches. They are known to parasitize a wide variety of small and large ruminants and are responsible for substantial economic loss. In India, reports on the prevalence of these flukes have been archived from all the major provinces. Gastrothylax crumenifer (Gc) is a commonly found amphistome parasite infecting the rumen of the Indian Water buffalo, Bubalus bubalis in this part of north India. In general, the adult forms of amphistome parasites manifest diminished pathogenicity, but the immature rumen flukes during their course of migration lead to severe pathological disturbances including hemorrhagic inflammation in the

\footnotetext{
Copyright: Ahmed, et al. Open Access. This article is distributed under the terms of the Creative Commons Attribution 4.0 International License (http://creativecommons.org/licenses/ by/4.0/), which permits unrestricted use, distribution, and reproduction in any medium, provided you give appropriate credit to the original author(s) and the source, provide a link to the Creative Commons license, and indicate if changes were made. The Creative Commons Public Domain Dedication waiver (http:// creativecommons.org/publicdomain/zero/1.0/) applies to the data made available in this article, unless otherwise stated.
}

wall of alimentary tract [2]. In India, several outbreaks of acute amphistomosis associated with high mortality among young sheep, goats, cattle, and buffaloes have been recorded [3-6]. In the absence of commercial vaccine, chemotherapy is the only way to deal with these rampant and neglected epidemic infections, but reports on emerging anthelmintic resistance have necessitated the quest to find new drug targets and promising vaccine candidates.

Glutathione S-transferases (GSTs) are a diverse family of multifunctional proteins that find widespread distribution in the aerobic organisms. GSTs mediate the covalent addition of the tripeptide glutathione (GSH) to a structurally diverse set of electrophiles [7]. GST enzymes are involved in the active detoxification of xenobiotics by conjugation to GSH. They are also known to neutralize endogenous secondary metabolite formed during oxidative stress [8]. These enzymes occur in multiple forms and catalyze a multitude of reactions involving electrophilic functional groups [9]. The GST has got a principal role in the process of inactivating a wide range of exogenous/endogenous toxic molecules and to turn them into water-soluble compounds. GSTs gained vital significance in parasites as the main detoxification system due to the lack of cytochrome P450 (CYP450) 
activity [10]. It has been postulated that GSH mediated antioxidant system is responsible for the prolong survival of helminth parasites in the mammalian definitive host. Occurrence of GSTs in helminth parasites protect them from the reactive oxygen species (ROS) generated during normal metabolism and by the immune effector cells of the invaded host $[11,12]$. The inherent capacity of helminth GSTs to neutralize cytotoxic components furnished by ROS of host origin on cell membrane strengthens the potential of GSTs as a protective tool against the host immune response. The inhibition of helminth GSTs dismantles the parasite defense against mounting oxidative stress and immunogenic attack of the host $[13,14]$. These facts place them as targets for the development of vaccines or chemotherapeutic agents $[15,16]$. The discovery and exploration of biochemical attributes of GSTs in helminth parasites have resulted into elaborate testing of this enzyme form as a target immunoprotective antigen.

There are many reports available on these vaccination experiments [17-20]. Therefore, to cater to that need, preliminary studies were designed and executed to purify and characterize GST from Gc to generate a baseline data which could further be exploited for immune and chemotherapeutic assessments to check amphistome infections in domesticated ruminants.

\section{Materials and Methods}

\section{Ethical approval}

Ethical approval is not necessary to pursue this type of study.

\section{Collection of parasites}

Mature and active Gc amphistome parasites were collected from the rumen of the Indian water buffalo (B. bubalis) slaughtered at Aligarh abattoirs. The parasites were thoroughly washed in phosphate buffered saline (100 mM, pH 7.4) and then briefly rinsed in the same washing buffer containing $0.01 \%$ penicillin-streptomycin (Merck, Germany) solution to remove any possible microbial contamination.

\section{Preparation of somatic extracts}

The parasites were homogenized in a chilled mortar-pestle over ice in cold phosphate buffer solution $(100 \mathrm{mM}, \mathrm{pH} 7.4)$. The sample was centrifuged at $10,000 \times g$ for $10 \mathrm{~min}$ in a refrigerated centrifuge (Hitachi, Japan) and the supernatants were collected as soluble protein fractions.

\section{Protein estimation}

The protein contents were estimated following the dye binding method of Bradford [21] as modified by Spector [22]. Bovine serum albumin was used as a standard.

\section{Ammonium sulfate precipitation}

The soluble proteins of somatic extract of $\mathrm{Gc}$ were fractionated between $0-20 \%, 20-40 \%, 40-60 \%$, $60-80 \%$, and $80-100 \%$ ammonium sulfate saturation in a stepwise ascending grade of protein salting out method. After $4 \mathrm{~h}$, the precipitated proteins from each of the fractions were procured by centrifugation at $10,000 \times g$ for $30 \mathrm{~min}$ at $4^{\circ} \mathrm{C}$ in a cooling centrifuge (Remi, India).

\section{Dialysis of samples}

A small portion of the supernatants from each salting out step was saved and the precipitate was dissolved in a minimum volume of $100 \mathrm{mM}$ sodium phosphate buffer $(\mathrm{pH}$ 7.4). The supernatant and the precipitate obtained from each salting out step were dialyzed separately thrice against $1200 \mathrm{ml}$ of the same buffer overnight at $4^{\circ} \mathrm{C}$ to remove ammonium sulfate content from the protein samples.

\section{Protein estimation of each fraction}

The protein content of the dialyzed supernatant and precipitated samples were estimated as mentioned earlier.

\section{Assay of GST enzyme}

Following protein estimation, all the supernatant and ammonium sulfate precipitated samples of Gc were assayed spectrophotometrically to determine the activity of GST enzyme. The precipitated fractions with maximum GST specific activity were selected and processed for gel filtration chromatography.

\section{Gel filtration chromatography}

A Sephacryl S 100-HR column (Sigma-Aldrich, USA) was prepared as recommended by Peterson and Sober [23] with necessary adjustments and modifications. Pre-swollen gel suspended in ethanol was soaked in sufficient amount of double distilled water and washed at least thrice. The finer resin fragments were removed by suspending the gel in two- to fourfold excess of $100 \mathrm{mM}$ sodium phosphate buffer, $\mathrm{pH} 7.4$ and the gel was allowed to settle down. A glass column $(70 \mathrm{~cm} \times 2 \mathrm{~cm})$ was mounted on a sturdy vertical support after introducing the glass wool on its opening near the bottom end which was fitted with rubber tubing. Following the clamping of rubber tubing, the column was filled to one-third of its length with operating buffer to check leaks and flush air bubbles from the dead space. The de-aerated gel slurry was poured with the help of a glass rod into the column with care to avoid generating air bubbles. The column was left to stand overnight. Flow rate was increased gradually, and after achieving a constant flow rate (higher than that required for final elution), the column was adjusted to the required flow rate. The packed column was thoroughly washed with two-bed volumes of operating buffer $(100 \mathrm{mM}$ sodium phosphate buffer, $\mathrm{pH}$ 7.4). To check uniform packing and to determine void volume of the column, $2 \%(\mathrm{w} / \mathrm{v})$ solution of blue dextran in $100 \mathrm{mM}$ sodium phosphate buffer ( $\mathrm{pH}$ 7.4) was passed through the column. The volume of the blue dextran and protein solution applied was not more than $2-3 \%$ of the total bed volume. The dialyzed sample was subjected to gel filtration chromatography on Sephacryl S-100-HR column equilibrated with $100 \mathrm{mM}$ sodium phosphate buffer, 
$\mathrm{pH} 7.4$ at $4^{\circ} \mathrm{C}$. The flow rate of the column was set at $15 \mathrm{ml} / \mathrm{h}$ during the process of filtration. Fractions of $5 \mathrm{ml}$ were collected and assayed for protein content and GST activity. Homogeneity of the purification was analyzed by $12 \%$ sodium dodecyl sulfate polyacrylamide gel electrophoresis (SDS-PAGE).

\section{Collection of eluents}

The eluents containing protein samples were collected into 14 subsequent fractions $(5 \mathrm{ml})$ and were assayed for protein content and GST activity.

\section{GST activity in each eluent}

The eluted fractions showing detectable amount of protein content were assayed to determine GST enzyme activity in a UV-visible spectrophotometer (Taurus Scientific, U.S.A). GST activity was determined by the method of Habig et al. [24] with minor modifications. The assay was performed in a total volume of $3.0 \mathrm{ml}$ reaction mixture containing $300 \mu 1$ of $1.0 \mathrm{mM}$ reduced GSH, $10 \mu \mathrm{l}$ of $1.0 \mathrm{mM}$ 1-chloro-2,4-dinitrobenzene (CDNB), and $50 \mu 1$ of protein samples. The remaining volume was adjusted with $0.1 \mathrm{M}$ sodium phosphate buffer (pH 6.5). CDNB and GSH were dissolved in ethanol and $0.1 \mathrm{M}$ sodium phosphate buffer ( $\mathrm{pH}$ 6.5), respectively. The control assay mixture did not have any protein (enzyme) sample. The assay was carried out at least in three replicates. The change in absorbance at $340 \mathrm{~nm}$ was recorded for $3 \mathrm{~min}$. The change in absorbance was calculated and used for determining the enzyme specific activity. The GST activity is defined as the amount of enzyme that catalyzes the formation of $1.0 \mu \mathrm{mol}$ of S-(2,4-dinitrophenyl) GSH/ $\mathrm{min} / \mathrm{mg}$ protein under the standard assay conditions. The unit of enzyme activity is expressed as nmoles/ $\mathrm{mg}$ protein/minute.

\section{Molecular weight determination of GST enriched fraction by SDS-PAGE}

The eluted fractions showing highest activity for GST were subjected to SDS-PAGE to assess the homogeneity of purification as well as relative percentage of GST protein in the GST enriched fractions. All the samples and buffers used in this study were filtered through $0.22 \mu \mathrm{m}$ Millipore filters to remove small particles and the gel solutions were additionally degassed before gel polymerization.

\section{Protein loading and electrophoresis}

Eluted fractions containing highest GST activity in Gc were separately mixed with the SDS sample buffer containing $\beta$-mercaptoethanol in the ratio of 1:2 (Sample: Sample buffer) and then the mixture was heated for $3-5 \mathrm{~min}$ at $95^{\circ} \mathrm{C}$ in water bath. Samples were loaded in different wells along with the standard protein markers (Precision Plus Protein ${ }^{\mathrm{TM}}$ Dual Color Standard; BIO-RAD) in a separate lane. After that, the gels were placed in a Benchtop Mini-Boat gel electrophoresis assembly and then running buffer was poured into the buffer tank. Electrophoresis [25] was carried out at $100 \mathrm{~V}$ for $60 \mathrm{~min}$ at RT. The gels were then carefully removed and thoroughly washed twice with distilled water before incubation in CBBR-250 solution overnight at RT. The over stained gels were destained, photographed, and analyzed.

\section{Native-PAGE for GST activity determination}

\section{Gel preparation}

To resolve the isozyme pattern and activity of GST enzyme molecules, the polyacrylamide gels were cast between glass cassettes in an electrophoresis assembly. A $12 \%$ separating gel and stacking gel of $5 \%$ concentration were prepared.

\section{Protein loading and electrophoresis}

Samples (desired eluted fractions of Gc) were mixed with the non-reducing sample buffer in the ratio of 1:2 (sample: sample buffer) and then the mixture was held at $4^{\circ} \mathrm{C}$ for $2-4 \mathrm{~h}$. The prepared samples were loaded and electrophoresis was done at $100 \mathrm{~V}$ for $90 \mathrm{~min}$.

\section{Activity of GST in native polyacrylamide gel}

The activity of GST enzyme in gel was performed according to the protocol of Ricci et al. [26]. The electrophoresed gels were then incubated in a series of reagents to develop achromatic bands depicting GST isozyme.

\section{Photography of stained gels}

The stained gels were scanned on a computer-driven laser scanner for analysis and all the images were saved for further analysis as well as to maintain digital record in the laboratory.

\section{Effect of $p H$ on partially purified GST}

Variation in the enzyme activity of partially purified GST obtained from Gc was examined at various $\mathrm{pH}$ values $(5.0,5.5,6.0,6.5,7.0,7.5,8.0,8.5$, and 9.0). Purified GST enzymes (1 $\mathrm{mg}$ ) from the amphistome parasites were incubated separately in $1 \mathrm{ml}$ of $100 \mathrm{mM}$ sodium phosphate buffered solution having different $\mathrm{pH}$ at a constant temperature of $4^{\circ} \mathrm{C}$ for $30 \mathrm{~min}$. Following incubation, each sample was assayed for GST activity as mentioned above.

\section{Effect of temperature on partially purified GST}

The variation in specific activity of GST from $\mathrm{Gc}$ was also investigated as a function of five different temperature $(4,25,37,60 \text {, and } 80)^{\circ} \mathrm{C}$. Purified GST enzymes $(1 \mathrm{mg})$ were incubated separately in $1 \mathrm{ml}$ of sodium phosphate buffered solution $(100 \mathrm{mM}, \mathrm{pH} 7.4)$ pre-maintained at specific temperatures, for $30 \mathrm{~min}$. Following incubation, each sample was assayed for GST activity according to the methods mentioned earlier.

\section{Results}

The present work deals with the partial purification of GST protein from the somatic tissues of amphistome parasites, Gc. The methodology involved 
two steps isolation process using tissue homogenates. The aqueous protein extracts were subjected to ammonium sulfate precipitation (40-60\%) for Gc. The precipitated protein fractions from the flukes were passed through a Sephacryl S-100 HR column. Different steps of typical purification process of GST proteins, their specific enzyme activity, fold purification, and percent yield are summarized in Table-1. Fractionation of the soluble proteins with ammonium sulfate decreased the total amount of protein obtained in the subsequent precipitate. The ammonium sulfate precipitation $(40-60 \%)$ revealed $47.74 \%$ yield of the total activity in crude protein but the GST protein showed 2.78-fold purification as compared to the crude homogenate of Gc.

\section{Gel filtration chromatography}

The ammonium sulfate precipitated proteins (40$60 \%$ ) obtained were chromatographed on a Sephacryl S-100 HR column pre-equilibrated with $100 \mathrm{mM}$ sodium phosphate buffer ( $\mathrm{pH}$ 7.4). Single peak showing highest GST specific enzyme activity (24.677 nmoles/mg protein/min) was obtained for the rumen flukes as shown in Figure-1. The sixth eluted fraction corresponding to the peak was used for further analyses. It was observed that the size exclusion chromatography could purify the GST protein by 22.27 -folds from crude homogenates of Gc. The percent yields of GST protein after size exclusion chromatography in Gc were found to be 18.61 as compared to their corresponding crude forms (Table-1).

\section{Homogeneity of the purified GST proteins}

Eluted GST proteins from Gc showed a single peak corresponding to highest enzyme specific activity suggested a homogenous soluble extract preparation (Figure-1). In addition, the preparations had minimum interference with the ions of sodium and phosphates as are evident from the symmetric peaks and patterns of eluting fractions in terms of protein content and GST specific activity. Physical evidence for homogeneity was further provided by PAGE.

\section{Reducing SDS-PAGE}

Partially purified GST proteins from Gc (Eluted fraction-6) were analyzed on PAGE under reducing and non-reducing (in absence of SDS and $\beta$-mercaptoethanol) conditions. The PAGE (12\%) profile under reducing conditions showed that the GST migrated as a single prominent band in the parasites under study (Figure-2a). The specific polypeptides corresponding to GST

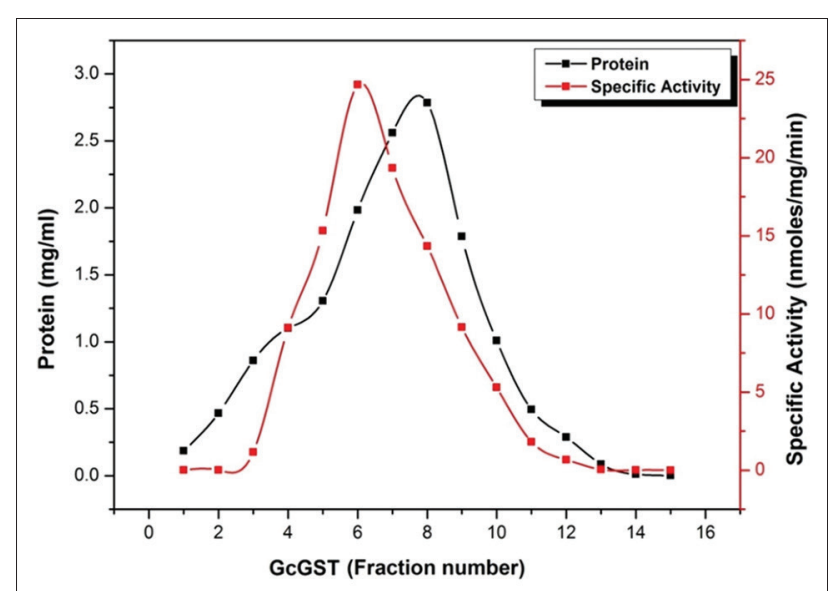

Figure-1: Elution profile of $40-60 \%$ ammonium sulfate precipitated protein fraction of Gastrothylax crumenifer as obtained by gel filtration chromatography on Sephacryl S-100 HR gel matrix.

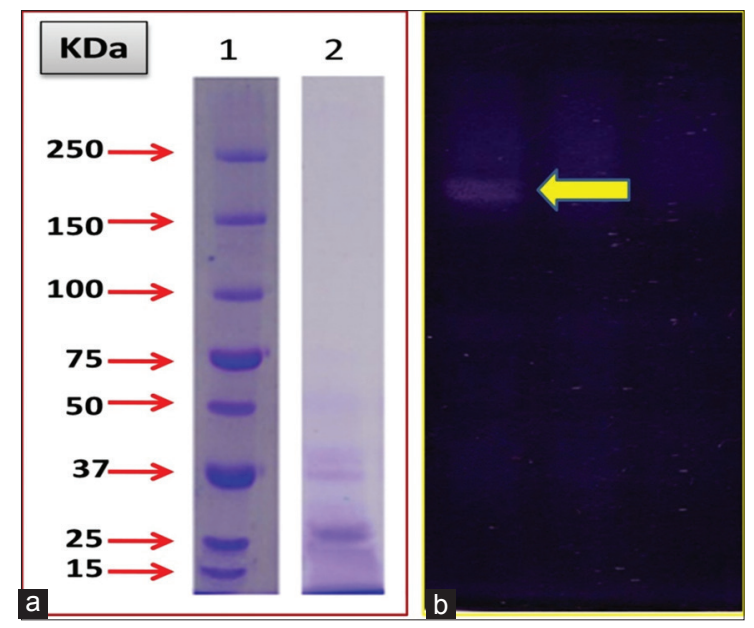

Figure-2: (a) Sodium dodecyl sulfate polyacrylamide gel electrophoresis (PAGE) analysis of purified glutathione S-transferase (GST) from Gastrothylax crumenifer (Gc) in a $12 \%$ gel. Lane 1 - standard protein marker (SPM), Lane 2 - purified GST from Gc (GcGST). (b) In-gel activity of purified GST from Gc in $10 \%$ native PAGE gel. The activity band appears as an achromatic zone on a blue insoluble formazan background.

Table-1: Different steps involved in the purification of GST proteins obtained from the somatic tissues of Gastrothylax crumenifer (GcGST).

\begin{tabular}{|c|c|c|c|c|c|c|}
\hline $\begin{array}{l}\text { Steps of } \\
\text { purification }\end{array}$ & $\begin{array}{l}\text { Total volume } \\
\text { (ml) }\end{array}$ & $\begin{array}{l}\text { Total protein } \\
(\mathbf{m g})\end{array}$ & $\begin{array}{c}\text { Total } \\
\text { activity } \\
\text { (n moles) }\end{array}$ & $\begin{array}{c}\text { Specific activity } \\
\text { (nmoles/mg protein } / \mathrm{min})\end{array}$ & $\begin{array}{c}\text { Fold } \\
\text { purification }\end{array}$ & $\begin{array}{l}\text { Percent } \\
(\%) \text { yield }\end{array}$ \\
\hline $\begin{array}{l}\text { Crude } \\
\text { homogenate }\end{array}$ & 65 & 1187.355 & 1315.300 & 1.108 & 1 & 100 \\
\hline $\begin{array}{l}(40-60) \% \\
\text { Ammonium } \\
\text { sulfate precipitate }\end{array}$ & 10 & 203.510 & 628.000 & 3.086 & 2.785 & 47.746 \\
\hline $\begin{array}{l}\text { Gel filtration } \\
\text { (Sephacryl } \\
\text { S-100 HR) }\end{array}$ & 6 & 9.920 & 244.800 & 24.677 & 22.272 & 18.612 \\
\hline
\end{tabular}

GST=Glutathione S-transferase 
monomeric proteins in the rumen amphistomes were observed to be lying in the low molecular weight range.

\section{Non-reducing (native) PAGE}

Partially purified GST proteins from the eluted fraction number 6 for Gc (GcGST) were analyzed on native PAGE under non-reducing conditions. Subsequent staining of the gel matrix for in-gel activity of GST revealed a single achromatic band over a blue insoluble formazan dark background (Figure-2b).

\section{Properties of the partially purified GST proteins}

\section{Molecular weight determination}

Analysis of the resolved polypeptide on a $12 \%$ SDS polyacrylamide gel in a Bio Rad Gel Documentation system revealed a single band of $26 \mathrm{kDa}$ polypeptide corresponding to GST monomer (Figure-2a).

\section{Effect of $\mathrm{pH}$ on partially purified GST}

Effect of $\mathrm{pH}$ on the specific activity of partially purified GST was examined at various $\mathrm{pH}$ values ranging from 5.0 to 9.0 (Figure-3). The GST activities in the parasitic flukes were seen to be drastically affected at both the extreme of the test range. The GST proteins were found to have considerable enzymatic activities in a $\mathrm{pH}$ range of 6.5-8.5 in the parasite under study. Maximum stability of the catalytic properties of GST proteins was observed at $\mathrm{pH} 7.5$ (Figure-3). A rise in $\mathrm{pH}$ from 7.5 to 8.0 resulted in an evident decrease in the enzyme activity. This suggests that the GST enzyme in this amphistome parasite has specific $\mathrm{pH}$ optima.

\section{Effect of temperature on partially purified GST}

Alteration in the specific activity of GST from Gc was also investigated as a function of temperature in a range from 4 to $80^{\circ} \mathrm{C}$ for $30 \mathrm{~min}$. The GST protein remained considerably active within the temperature of $4-37^{\circ} \mathrm{C}$ for the parasite species (Figure-4). However, a rise in temperature from 25 to $30^{\circ} \mathrm{C}$ resulted into sharp decline in the GST specific activity profile in

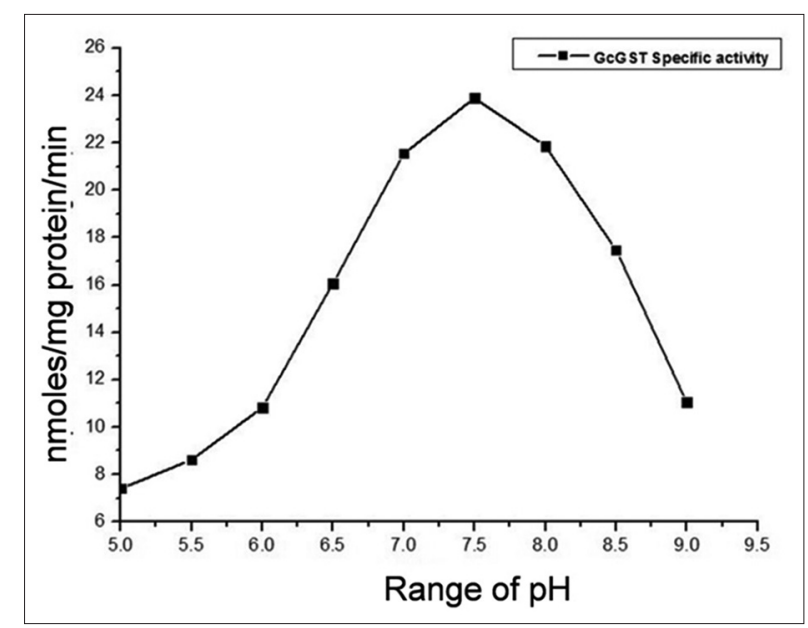

Figure-3: The $\mathrm{pH}$ stability of the purified glutathione S-transferase (GST) proteins from Gastrothylax crumenifer in $100 \mathrm{mM}$ sodium phosphate buffer having different $\mathrm{pH}$ (5.0-9.0). Purified GSTs (1 mg) were incubated in $1 \mathrm{ml}$ of phosphate buffer solution at $4^{\circ} \mathrm{C}$ for $30 \mathrm{~min}$. the parasites under study (Figure-4). When the temperature was raised from 4 to $25^{\circ} \mathrm{C}$, the abrupt slump in the activities of GST proteins was recorded. This suggested that GST from Gc is appreciably robust in terms of minor thermal fluctuations at lower temperature ranges.

\section{Discussion}

GSTs exist in all living organisms and they are involved in various detoxification pathways and antioxidant processes. Since, helminth parasites lack p-450 monoxygenases, the Phase-II biotransformations are carried out by GST isoforms and hence are of cardinal importance [27]. GSTs perform several important functions in the body and are associated with several pathological conditions including cancer [28], rheumatoid arthritis [29], osteoporosis [30], renal dysfunctions [31], cardiovascular diseases [32,33], and Alzheimer's disease [34]. GSTs have been purified and characterized from various helminth parasites including nematodes, trematodes, and cestodes such as Clonorchis sinensis [35], Setaria digitata [36], Schistosoma mansoni [37], Schistosoma japonicum [38], Fasciola hepatica [39], Necator americanus [40], and Echinococcus granulosus [41]. Due to lack of information on GSTs from a neglected group of digenetic trematodes, the amphistome parasites, present work has been carried out. To the best of our knowledge, this is the first description about the purification and properties of GST enzymes obtained from the amphistome parasites, Gc. It was envisaged that a thorough study on GST from the ruminal amphistomes will shed some light toward better understanding of GSTs of helminth origin. This will be useful in generating a base line data so that the salient enzymatic properties can be compared with other known GST from different parasitic fauna. In

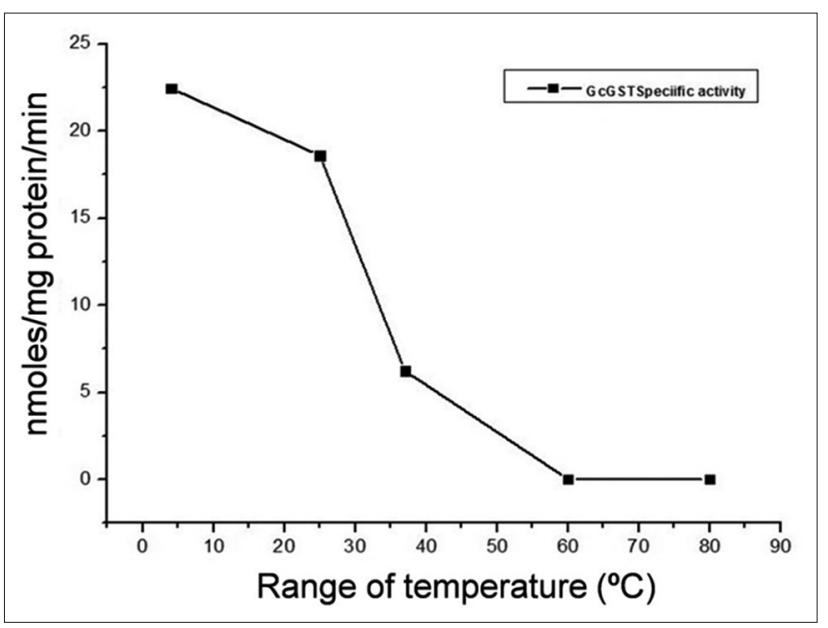

Figure-4: Thermal stability of the purified glutathione S-transferase (GST) proteins from Gastrothylax crumenifer in $100 \mathrm{mM}$ sodium phosphate buffer $(\mathrm{pH} 7.4)$ premaintained at five different temperatures $(4,25,37,60$, and $\left.80^{\circ} \mathrm{C}\right)$. Purified GSTs $(1 \mathrm{mg})$ were incubated in $1 \mathrm{ml}$ of phosphate buffer solution having different temperatures for $30 \mathrm{~min}$. 
the present work, GST was purified from Gc by the method as described in the materials and method section. The two step procedure involved ammonium sulfate fractionation and gel filtration chromatography. The simple isolation procedure provided a percent yield of 18.61- and 22.27-fold purification for Gc. Purification of the GST isozymes from a variety of helminth parasites has been reported using a combination of several methods including affinity chromatography, chromatofocusing, gel filtration, and ion exchange chromatography [12,14,42-44]. However, the procedure used in this study is simple and cost-effective which give appreciable yield and fold purification as compared to the values reported in literature for other helminth parasites [36]. The partially purified GST obtained from the amphistome parasites was found to be homogenous on the basis of charge as shown by native-PAGE. In SDS-PAGE under reducing conditions, GST from Gc gave a single band which could be of dimeric nature (native state) with two identical subunits.

GSTs obtained from amphistome parasites were partially purified on a Sephacryl S 100-HR resin matrix. The molecular mass of the subunits comprising the native GST molecule was found to be made up of two equal sub-units of $26 \mathrm{kDa}$ in $\mathrm{Gc}$ following denaturing PAGE technique in the presence of $\beta$-mercaptoethanol. Subunits of GST with comparable molecular weights $(26 \mathrm{kDa})$ have also been reported in a wide variety of helminths such as $S$. mansoni [37], S. japonicum [45], F. hepatica [46], Taenia solium [42], and Setaria cervi [43]. In general, cytosolic GSTs have monomers of 23-28 kDa with an average of 220 amino acids in their sequences. They all share the same tertiary and quaternary dimeric structural features. The dimer may have identical subunits (homodimer) or different subunits (heterodimer) of the same class [47]. In the present study, appreciable stability of the partially purified GSTs from Gc was observed in the broad range of $\mathrm{pH}(6.5-8.5)$ as well as temperature $\left(4-37^{\circ} \mathrm{C}\right)$. Similar kinds of observations were made with GST purified from $S$. digitata which showed good enzyme activity between $0^{\circ} \mathrm{C}$ and $40^{\circ} \mathrm{C}$, while a sharp decline in activity was observed beyond $40^{\circ} \mathrm{C}$ with complete loss of activity at $80^{\circ} \mathrm{C}$ [36]. A similar trend in the GST enzyme activity was reported earlier with temperature optima of around $40^{\circ} \mathrm{C}[42,43]$ and loss of activity at higher temperatures. The enzyme activity of GSTs from Gc was seen to vary with change in $\mathrm{pH}$. The optimum GST activities for this amphistome were observed at $\mathrm{pH}$ 7.5; a similar finding was also reported in GST purified from S. digitata [36].

In most of the helminth parasites, CYP450 mediated biotransformation has not been reported. Hence, the GST enzyme system plays an indispensible role in carrying out the Phase II detoxification pathways. Due to this, purified GSTs from various helminth parasites have been screened for immune and chemotherapeutic leads and targets to design and develop a better and reliable parasite control measure. The present study was an attempt to purify GST enzyme from an amphistome parasite to determine and obtain the basic biochemical attributes which could help in the formulation of new drug to control the amphistomosis in our farm animals.

\section{Conclusion}

The present study is an attempt to purify and conduct basic biochemical characterization of GST from the rumen infecting amphistome Gc using size exclusion chromatography.

\section{Authors' Contributions}

SA and AS prepared the study design and carried out the research under the supervision of MKS. SK and SHK isolated the parasites and analyzed the data. The manuscript was drafted and revised by SA and SK under the guidance of MKS. All authors read and approved the final manuscript.

\section{Acknowledgments}

The authors are grateful to the Chairman, Department of Zoology, Aligarh Muslim University, Aligarh, for providing necessary laboratory facilities. The first author is also thankful to the University Grants Commission (UGC), Government of India, for financial assistance in the form of MAN-JR and MAN-SR fellowships (Grant number: F1-17.1/2010/ MANF-MUS-JHA-2014/(SA-III).

\section{Competing Interests}

The authors declare that they have no competing interests.

\section{References}

1. Toledo, R. and Fried, B. (2014) Advances in Experimental Medicine and Biology 766 (Digenetic Trematodes). Springer Publications, Springer Science+Business Media, New York. p365-392.

2. Saifullah, M.K., Ahmad, G. and Abidi, S.M.A. (2013) Immunodetection of coproantigens for the diagnosis of amphistomosis in naturally infected Indian Water Buffalo, Bubalus bubalis. Vet. Parasitol., 191: 66-72.

3. Chauhan, V.D., Patel, P.V., Hasnani, J.J., Pandya, S.S., Pandey, S., Pansuriya, D.V. and Choudhary, V. (2015) Study on hematological alterations induced by amphistomosis in buffaloes. Vet. World., 8(3): 417-420.

4. Kumar, B., Maharana, B.R., Prasad, A., Joseph, J.P., Patel, B. and Patel, J.S. (2016) Seasonal incidence of parasitic diseases in bovines of south western Gujarat (Junagadh), India. J. Parasit. Dis., 40(4): 1342-1346.

5. Dixit, A.K., Das, G. and Baghel, R.P.S. (2017) Gastrointestinal helminthosis: Prevalence and associated determinants in goats of Jabalpur, India. J. Parasit. Dis., 41(2): 414-416.

6. Sorathiya, L.M., Fulsoundar, A.B., Rao, T.K.S. and Kumar, N. (2017) Prevalence and risk factors for gastrointestinal parasitism in traditionally maintained goat flocks of South Gujarat. J. Parasit. Dis., 41(1): 137-141.

7. Sheehan, D., Meade, G., Foley, V.M. and Dowd, C.A. (2001) Structure, function and evolution of glutathione transferases: Implications for classification of non-mammalian members of an ancient enzyme superfamily. Biochem. J., 360: 1-16. 
8. Lu, J. and Holmgren, A. (2014) The thioredoxin antioxidant system. Free Radic. Biol. Med., 66: 75-87.

9. Mannervik, B. (1985) The isoenzymes of glutathione transferases. Adv. Enzymol. Relat. Areas Mol. Biol., 57: 357-417.

10. Callahan, H.L., Crouch, R.K. and James, E.R. (1988) Helminth anti-oxidant enzymes: A protective mechanism against host oxidants? Parasitol. Today, 4(8): 218-225.

11. Brophy, P.M. and Pritchard, D.I. (1992) Immunity to helminths: Ready to tip the biochemical balance? Parasitol. Today, 8(12): 419-422.

12. Brophy, P.M. and Barret, J. (2009) Glutathione-S-transferase in helminthes. Parasitology, 100: 345-349.

13. Brophy, P.M. and Pritchard, D.I. (1994) Parasitic helminth glutathione S-transferases: Update on their potential for immuno and chemotherapy. Exp. Parasitol., 79(1): 89-96.

14. Liebau, E., Wildenburg, G., Brophy, P.M., Walter, R.D. and Henkle, D.K. (1996) Biochemical analysis, gene structure and localization of the $24 \mathrm{kDa}$ glutathione S-transferase from Onchocerca volvulus. Mol. Biochem. Parasitol., 80: 27-39.

15. Brophy, P.M., Ben-Smith, A., Brown, A., Behnke, J.M. and Pritchard, D.I. (1994) Glutathione S-transferase from the gastrointestinal nematode Heligmosomoides polygyrus and mammalian liver compared. Comp. Biochem. Physiol. B, 109(4): 585-592.

16. Barrett, J. (1998) Cytochrome P450 in parasitic protozoa and helminths. Comp. Biochem. Physiol. C, 121(1-3): 181-183.

17. Bourke, C.D., Nausch, N., Rujeni, N., Appleby, L.J., Trottein, F., Midzi, N., Mduluza, T. and Mutapi, F. (2014) Cytokine responses to the anti-schistosome vaccine candidate antigen glutathione-S-transferase vary with host age and are boosted by praziquantel treatment. PLoS Negl. Trop. Dis., 8(5): e2846.

18. Li, L.G., Wang, Z.Q., Liu, R.D., Yang, X., Liu, L.N., Sun, G.G., Jiang P., Zhang, X., Zhang, G.Y. and Cui, J. (2015) Trichinella spiralis: Low vaccine potential of glutathione S-transferase against infections in mice. Acta Trop., 146: 25-32.

19. Mbanefo, E.C., Kumagai, T., Kodama, Y., Kurosaki, T., Furushima-Shimogawara, R., Cherif, M.S., Mizukami, S., Kikuchi, M., Huy, N.T., Ohta, N., Sasaki, H. and Hirayama, K. (2015) Immunogenicity and anti-fecundity effect of nanoparticle coated glutathione S-transferase (SjGST) DNA vaccine against murine Schistosoma japonicum infection. Parasitol. Int., 64(4): 24-31.

20. Diemert, D.J., Freire, J., Valentene, V., Fraga, C.G., Taller, F., Grahek, S., Campbell, D., Amar, J., Maria, V.P., Martin, E., Maria, F.G. and Maria, E.B. (2017) Safety and immunogenicity of the Na-GST-1 hookworm vaccine in Brazilian and American adults. PLoS Negl. Trop. Dis., 11(5): e0005574.

21. Bradford, M.M. (1976) A rapid and sensitive method for the quantitation of microgram quantities of protein utilizing the principle of protein dye binding. Anal. Biochem., 72: $248-254$.

22. Spector, T. (1978) Refinement of the coommassie blue method of protein quantitation. Anal. Biochem., 86(1): 142-146.

23. Peterson, E.A. and Sober, H.A. (1962) In: Colowick, S.P. and Kaplan, N.O., editor. Methods in Enzymology. $3^{\text {rd }}$ ed., Vol. 5. Academic Press Inc., New York.

24. Habig, W.H., Pabst, M.J. and Jakoky, W.B. (1974) The first enzymatic step in mercapturic acid formation. J. Biol. Chem., 249(22): 7130-7139.

25. Laemmli, U.K. (1970) Cleavage of structural proteins during the assembly of the head of bacteriophage T4. Nature, 227(5259): 680-685.

26. Ricci, G.M., Lo Bello, A.M., Caccuri, F., Galiazzo, F. and Federici, G. (1984) Detection of glutathione transferase activity on polyacrylamide gels. Anal. Biochem. 143(2): 226-230.

27. Precious, W.Y. and Barrett, J. (1989) Xenobiotic metabolism in helminths. Parasitol. Today, 5(5): 156-160.

28. Marchewka, Z., Piwowar, A., Ruzik, S. and Długosz, A. (2017) Glutathione S-transferases class $\mathrm{Pi}$ and $\mathrm{Mi}$ and their significance in oncology. Postepy Hig. Med. Dosw., 71: 541-550.

29. Mateen, S., Moin, S., Khan, A.Q., Zafar, A. and Fatima, N. (2016) Increased reactive oxygen species formation and oxidative stress in rheumatoid arthritis. PLoS One, 11(4): e0152925.

30. Ragab, S.M., Badr, E.A. and Ibrahim, A.S. (2016) Evaluation of glutathione-S-transferase P1 polymorphism and its relation to bone mineral density in Egyptian children and adolescents with beta-thalassemia major. Mediterr. $J$. Hematol. Infect. Dis., 8(1): e2016004.

31. Shu, K.H., Wang, C.H., Wu, C.H., Huang, T.M., Wu, P.C., Lai, C.H., Tseng, L.J., Tsai, P.R., Connolly, R. and Wu, V.C. (2016) Urinary pi- glutathione S-transferase predicts advanced acute kidney injury following cardiovascular surgery. Nat. Sci. Rep., 6: 26335.

32. Balatonyi, B., Gasz, B., Kovács, V., Lantos, J., Jancsó, G., Marczin, N. and Rőth, E. (2013) The role of the inhibition of glutathione-S-transferase in the protective mechanisms of ischemic post conditioning. Can. J. Physiol. Pharmacol., 91(8): 625-632.

33. Phulukdaree, A., Khan, S., Moodley, D. and Chuturgoon, A.A. (2012) GST polymorphisms and early-onset coronary artery disease in young South African Indians. S. Afr. Med. J. 102(7): 627-630.

34. de Mendonça, E., Salazar-Alcalá, E. and FernándezMestre, M. (2014) Role of genes GSTM1, GSTT1, and MnSOD in the development of late-onset Alzheimer disease and their relationship with $\mathrm{APOE}^{*} 4$. Neurologia, 31(8): 535-542.

35. Kim, J.G., Ahn, C.S., Kim, S.H., Bae, Y.A., Kwon, N.Y., Kang, I., Yang, H.J., Sohn, W.M. and Kong, Y. (2016) Clonorchis sinensis omega-class glutathione transferases play major roles in the protection of the reproductive system during maturation and the response to oxidative stress. Parasit. Vectors, 9(1): 337.

36. Srinivasan, L., Mathew, N., Karuna, T. and Muthuswamy, K. (2011) Biochemical studies on glutathione S-transferase from the bovine filarial worm Setaria digitata. Parasitol. Res., 109(1): 213-219.

37. O'Leary, K.A., Hathaway, K.M. and Tracy, J.W. (1992) Schistosoma mansoni: single-step purification and characterization of glutathione S-transferase isoenzyme 4. Exp. Parasitol., 75(1): 47-55.

38. Smith, D.B. and Johnson, K.S. (1988) Single-step purification of polypeptides expressed in Escherichia coli as fusions with glutathione S-transferase. Gene, 67(1): 31-40.

39. Panaccio, M., Wilson, L.R., Crameri, S.L., Wijffels, G.L. and Spithill, T.W. (1992) Molecular characterization of cDNA sequences encoding glutathione-S-transferases of Fasciola hepatica. Exp. Parasitol., 74(2): 232-237.

40. Asojo, O.A. and Ceccarelli, C. (2014) Structure of glutathione S-transferase 1 from the major human hookworm parasite Necator americanus (Na-GST-1) in complex with glutathione. Acta Crystallogr. F. Struct. Biol. Commun., 70: 1162-1166.

41. Fleitas, A.L., Randall, L.M., Möller, M.N. and Denicola, A. (2016) Purification of a recombinant glutathione transferase from the causative agent of hydatidosis, Echinococcus granulosus. Biochem. Mol. Biol. Educ., 44(1): 28-33.

42. Plancarte, A., Rendon, J.L. and Landa, A. (2004) Purification, characterization and kinetic properties of the Taenia solium glutathione S-transferase isoform $26.5 \mathrm{kDa}$. Parasitol. Res., 93(2): 137-144.

43. Gupta, S., Singh, A., Yadav, M., Singh, K. and Rathaur, S. (2007) MALDI mass sequencing and characterization of filarial glutathione-S-transferase. Biochem. Biophys. Res. Commun., 356(2): 381-385.

44. Ahmad, R., Srivastava, A.K. and Walter, R.D. (2008) 
Purification and biochemical characterization of cytosolic glutathione S-transferase from filarial worms Setaria cervi. Comp. Biochem. Physiol., 151(3): 237-245.

45. Walker, J., Crowley, P., Moreman, A.D. and Barrett, J. (1993) Biochemical properties of cloned glutathione S-transferases from Schistosoma mansoni and Schistosoma japonicum. Mol. Biochem. Parasitol., 61(2): 255-264.

46. Salvatore, L., Wijffels, G., Sexton, J.L., Panaccio, M.,
Mailer, S., McCauley, I. and Spithill, T.W. (1995)

Biochemical analysis of recombinant glutathione-S-transferase of Fasciola hepatica. Mol. Biochem. Parasitol., 69(2): 281-288.

47. Torres-Rivera, A. and Landa, A. (2008) Cooperative kinetics of the recombinant glutathione transferase of Taeniasolium and characterization of the enzyme. Arch. Biochem. Biophys. 477(2): 372-378.

$* * * * * * * *$ 